\title{
Preclinical test of a lentivirus-mediated RNAi gene therapy against HIV-AIDS in the humanized mouse model
}

\author{
Mireille Centlivre ${ }^{1 *}$, Nicolas Legrand ${ }^{2,3}$, Ying-Poi Liu', Karin J von Eíje ${ }^{1}$, Kees Weijer², Bianca Blom², Hergen Spits ${ }^{2,3}$, \\ Ben Berkhout ${ }^{1}$
}

From Frontiers of Retrovirology 2011

Amsterdam, The Netherlands. 3-5 October 2011

\section{Background}

HIV-1 is still a major public health problem and one of the priorities of the World Health Organization. The development of HAART against HIV was a considerable advance for infected individuals, but this life-long treatment does only block virus replication, and no viral eradication is obtained. Furthermore, HAART may exhibit long-term toxicity and may eventually lead to the emergence of drug-resistant viral variants. We explore a new durable therapeutic intervention based on a gene therapy that induces RNA interference (RNAi) against HIV1 . In this pre-clinical research setting, "humanized" experimental mouse models are of interest considering the relative ease of handling and relatively low cost as compared to non-human primates.

\section{Methods}

We have developed an RNAi gene therapy based on the transduction of human hematopoietic progenitor cells (HPC) with lentiviral vectors encoding short-hairpin RNAs to induce silencing of HIV genes. We have tested the efficacy and safety of such a shRNA-based gene therapy strategy in the "Human Immune System" (HIS) $\mathrm{BALB} / \mathrm{c} \mathrm{Rag} 2^{-1-} \mathrm{IL}-2 \mathrm{R} \gamma_{\mathrm{c}}{ }^{-/-}$mouse model, which are reconstituted with human HPC that were first transduced ex vivo with a lentiviral vector expressing the antiviral shRNAs.

Laboratory of Experimental Virology, Department of Medical Microbiology, Center for Infection and Immunity Amsterdam (CINIMA), Academic Medical Center of the University of Amsterdam (AMC-UvA), Amsterdam, The Netherlands

Full list of author information is available at the end of the article

\section{Results}

We observed a normal in vivo development of the human immune system with a good recovery of human shRNA+cells for the candidate shPol47, shPol1 and shRT5 inhibitors. However, the in vivo recovery of human shGag5-transduced cells was extremely poor, suggesting a negative impact of this specific shRNA on the development of the human immune system. When these 4 shRNAs were combined in a single lentiviral vector (R4), we observed a similar negative off-target effect due to the shGag5 component. Upon removal of shGag5 as in vector R3, transduction of human HPC results in a normal differentiation of the human immune system, highlighting the in vivo safety of this candidate R3 gene therapy vector for a clinical trial. Moreover, human HPC expressing the antiviral shNef generate human CD4+T cells with the ability to resist HIV-1 replication in a sequence specific manner.

\section{Conclusion}

Overall, these results underscore the usefulness of the HIS (BALB-Rag $/ \gamma$ ) mouse model for testing the safety and efficacy of durable anti-HIV gene therapy approaches. In this model, human HPC expressing antiHIV-1 shRNA give rise to multi-lineage reconstitution of the immune system in vivo and generate $\mathrm{CD} 4^{+} \mathrm{T}$ cells that are not susceptible for HIV-1 replication.

\footnotetext{
Author details

'Laboratory of Experimental Virology, Department of Medical Microbiology, Center for Infection and Immunity Amsterdam (CINIMA), Academic Medical Center of the University of Amsterdam (AMC-UvA), Amsterdam, The Netherlands. ${ }^{2}$ Department of Cell Biology \& Histology, Center for Immunology of Amsterdam (CIA), AMC-UvA, Amsterdam, The Netherlands. ${ }^{3}$ AIMM Therapeutics, AMC-UvA, Amsterdam, The Netherlands.
} 
doi:10.1186/1742-4690-8-S2-P9

Cite this article as: Centlivre et al.: Preclinical test of a lentivirusmediated RNAi gene therapy against HIV-AIDS in the humanized mouse model. Retrovirology 2011 8(Suppl 2):P9.

Submit your next manuscript to BioMed Central and take full advantage of:

- Convenient online submission

- Thorough peer review

- No space constraints or color figure charges

- Immediate publication on acceptance

- Inclusion in PubMed, CAS, Scopus and Google Scholar

- Research which is freely available for redistribution

Submit your manuscript at www.biomedcentral.com/submit 